\title{
DE TEGENWOORDIGE TOESTAND VAN SURINAME OP HET GEBIED VAN DEN LANDBOUW \\ DOOR
}

\section{J. BOONACKER}

Toen in de tachtiger jaren der vorige eeuw de cacaocultuur een voor Suriname loonend cultuurbedrijf beloofde te worden kon men de toekomst van Suriname's landbouw met meer vertrouwen tegemoet zien dan in langen tijd het geval was geweest. Immers de cacaocultuur bleek in die jaren zoowel voor den grooten als voor den kleinen man een bedrijf te zijn, dat behoorlijke winsten afwierp. Het aantal cacaoplantages nam langzamerhand toe, terwijl daarnaast eerst door den van het staatstoezicht ontslagen neger, later en in sneller tempo door den vrij geworden Britsch-Indischen immigrant $\mathrm{zg}$. gronden werden aangelegd, waarvan de beplanting hoofdzakelijk uit cacao bestond. Het was een hoogst eenvoudige cultuur en de bereiding van het product stelde aan de kennis van den planter geen al te hooge eischen. Daarnaast bestonden nog een 5-tal suikerondernemingen, die wel niet al te modern waren ingericht, maar die toch in vele jaren op vrij behoorlijke winsten konden rekenen. Kortom er was eenige verbetering te bespeuren in den oeconomischen toestand van het land en men had alle reden op goede hoop voor de toekomst.

Hoe anders is de toekomst echter geworden dan men zich die had voorgesteld! Nog voor het einde der vorige eeuw begonnen in de cacaoaanplantingen ziekten op te treden, die aanzienlijke schade aanrichtten en de cacaoproductie snel deden teruggaan. De bekende krullotenziekte tegelijk met herhaalde thripsaanvallen verzwakten de cacaoboomen in die mate, dat de daarop gevolgde in- 
stervingsziekte een groot deel van den aanplant kon verwoesten. In het begin van deze eeuw begon de cacaocultuur dan ook spoedig hare belangrijkheid voor Suriname te verliezen en thans neemt deze cultuur nog slechts een ondergeschikte plaats in.

Toen het zoo slecht met de cacaocultuur begon te gaan zijn er goed bedoelde pogingen in het werk gesteld om de teelt van andere gewassen in te voeren en aan te moedigen. De meest belovende dezer pogingen was ongetwijfeld de invoering van de bananencultuur grootendeels met steun van het Gouvernement. Aanvankelijk scheen dit behoorlijk opgezette cultuurbedrijf zeer goede uitkomsten te zullen opleveren. Maar het duurde ook al weer niet lang of er deden zich ernstige ziekteverschijnselen in de aangeplante variëteit voor, waarvan al heel spoedig bleek, dat zij de gunstige verwachtingen zouden te niet doen. En met voor de Panamaziekte immune variëteiten konden slechts korten tijd proeven worden genomen, want niet lang na het in ernstige mate optreden dezer ziekte trok de moederlandsche regeering haren steun in en hiermede behoorde de cultuur van bananen voor Suriname al weer tot het verleden. Dit bananendrama speelde zich in korten tijd af nl. tusschen de jaren 1906 en 1912.

Toen de vooruitzichten van de bananencultuur tengevolge van het optreden der Panamaziekte minder zeker begonnen te worden waren enkele ondernemers zoo verstandig, alhoewel dit in strijd was met de voorschriften, in de bananenvelden Liberiakoffie uit te zetten, waarvan in vroegeren tijd reeds was aangetoond, dat de teelt op de lage, zware kleingronden zeer goed mogelijk was en van welk gewas een 3-tal ondernemingen reeds aanzienlijke aanplantingen bezaten. Dit was het begin van de tegenwoordige koffiecultuur, die op het oogenblik met uitzondering van wat overbleef van de sukercultuur de eenige cultuur is van het grootbedrijf.

Te zelfder tijd dat men de bananencultuur ter hand nam begon men ook zijn aandacht te schenken aan de cultuur van den heveaboom, waartoe de hooge rubberprijzen van die dagen gereede aanleiding waren. Het parti- 
culier initiatief nam hierbij de leiding, terwijl later een Gouvernementsrubberonderneming volgde. Maar al spoedig bleek de Hevea Brasiliensis in de Surinaamsche polderlanden niet al te best op haar plaats. Niet alleen liet de groei in het algemeen te wenschen over, ook ziekten begonnen zich te vertoonen. Een dezer, de Zuid-Amerikaansche bladziekte, trad zelfs met zulk een hevigheid op, dat de Heveacultuur op de meeste ondernemingen moest worden opgegeven en de rubberplantage van het Gouvernement in een koffieonderneming moest worden omgezet.

Ten slotte valt nog te vermelden een poging om de katoencultuur in Suriname te doen herleven. Deze poging, een 7-tal jaren geleden van Amerikaansche zijde in het district Nickerie ondernomen, leed schipbreuk hoofdzakelijk tengevolge van het gebrek aan plaatselijke kennis en ondervinding van de leiders, die gewend aan drogere klimaten, geen voldoende rekening hielden met de eischen, die in Suriname aan de ontwatering dienen gesteld te worden. Tevens bleek op deze onderneming, waarbij voor het eerst althans op belangrijke schaal met mechanische tractie werd gewerkt, dat directe tractie op de zware Surinaamsche kleigronden minder op haar plaats is. Uit deze mislukte proefneming mag men dan ook mijns inziens allerminst de gevolgtrekking maken, dat herleving van de katoencultuur in Suriname tot de onmogelijkheden behoort.

Aan deze lange lijdensgeschiedenis heeft zich nu nog toegevoegd dealgemeene malaise, die tot gevolg heeft gehad een sterke daling van de koffie- en suikerprijzen. Zoodanig zelfs, dat zij de laatste twee jaren vrij belangrijk beneden den Surinaamsche kostprijs kwamen te liggen, waarmede de groote landbouw, die op het oogenblik wordt uitgeoefend op 4 suikerondernemingen en een 40-tal koffieplantages, in een bij uitstek noodlijdend stadium is gekomen. Van bestuurswege zijn maatregelen genomen tot het verleenen van steun aan de koffieondernemingen, maar de vorm, waarin deze steun tot nu toe verleend wordt, schijnt zich niet in de sympathie van de ondernemers te mogen verheugen. Aan de suikercultuur is eerst tegen het 
komende jaar eenige steun in uitzicht gesteld door een matige verlichting der lasten. Of deze hulp afdoende is en nog tijdig genoeg komt om de geheele stopzetting van 1 of meer der 4 suikerfabrieken te voorkomen moet ten sterkste in twijfel worden getrokken.

Voor den kleinen landbouw was de snelle achteruitgang van de cacaocultuur bijkans een nog grootere slag. Waar de plantages zich met steun van het Land door de bananencultuur eenige jaren konden staande houden was de kleine landbouw geheel op zichzelf aangewezen. Dat de kleine man toen het hoofd boven water heeft kunnen houden heeft hij in de eerste plaats te danken aan de rijstcultuur, welke cultuur hem om te beginnen zijn dagelijksche kost verschafte en hem daarnaast ook in staat stelde op bescheiden voet de andere onmisbare levensbehoeften te verkrijgen. Het in deze door den Britsch-Indiër genomen initiatief werd spoedig gevolgd door den zich als landbouwer nederzettenden Javaan, terwijl ook de inboorling op den duur wat meer belangstelling voor den rijstbouw aan den dag ging leggen. Toen in de oorlogsjaren het Bestuur terecht het belang inzag van een verhoogde rijstproductie ging het er toe over den rijstboeren steun te verschaffen door leiding te geven bij de inpoldering, ontwatering en bevloeiing op coöperatieven grondslag en soms te deelen in de kosten van dien aanleg. Hierdoor kwamen vooral in het district Nickerie verschillende rijstpolders tot stand. Het gevolg van een en ander was, dat de productie van rijst gestadig toenam en de laatste jaren een hoogte bereikte, die het zoeken van afzetgebieden buiten Suriname noodzakelijk maakte. Men slaagde hierin nog niet al te best, wat wel voor een groot deel te wijten is aan de onvoldoende kwaliteit van het afgewerkte product, anderdeels aan de weinige activiteit daarbij aan den dag gelegd. Door den onvoldoenden afzet is thans ook de rijstcultuur in een ongunstige positie gekomen.

In enkele daarvoor in aanmerking komende streken is de kleine landbouwer zich ook gaan toeleggen op de teelt van Liberiakoffie. Dit kon in hoofdzaak alleen daar geschieden waar in de nabijheid een fabriek voor de afwer- 
king van het product was gevestigd, voornamelijk dus op de vestigingen en vestigingsplaatsen aan de BenedenCommewijne en aan de Beneden-Suriname, in welke districten bijna alle koffieplantages zijn gelegen. Voor den kleinen landbouwer in andere gedeelten van Suriname is het vervoer van het ruwe product, de koffie in de bes, naar de ver afgelegen koffiefabrieken te moeilijk en te kostbaar. Het spreekt vanzelf, dat de kleine landbouwer nog meer het nadeel van de lage koffieprijzen voelt dan de groote landbouw, omdat de het product afwerkende fabriek nog eenige winst op de afwerking maakt en de kleine man financieel onmachtig is zijn product langen tijd te bewaren om bij opgaande koffieprijzen zijn voordeel te doen. Maar aan den anderen kant staat de kleine landbouwer weder sterker omdat hij geen vast werkvolk in dienst heeft, uit bijcultures inkomsten kan trekken en zich tevens in vele gevallen kan bezig houden met de teelt van melk-, slacht- en pluimvee.

In het district Coronie heeft de teelt van den kokospalm belangrijke proporties aangenomen. De kokospalm groeit daar bij uitstek goed en heeft er over het geheel weinig last van ziekten of plagen. Wel heeft de hartrotziekte er in sommige tijden veel sterfte in de boomen veroorzaakt, maar ten slotte heeft een goed doorgevoerde bestrijding erger kwaad kunnen voorkomen. De kokosteelt is in Coronie dan ook de voornaamste cultuur van het kleinbedrijf gebleven, dat daar hoofdzakelijk in handen is van inboorlingen. Naast de kokoscultuur legt men er zich toe op de varkensfokkerij, terwijl ook de laatste jaren meer aan den verbouw van rijst wordt gedaan. De afvalproducten, verkregen bij de bereiding van kokosolie, en de bij de pelling van rijst overblijvende zemelen, zijn van waarde voor de voeding der varkens. Alhoewel ook de prijzen van kokosnoten, kokosolie en varkens den laatsten tijd sterk zijn gedaald zou ik niet durven beweren, dat het kleinlandbouwbedrijf in Coronie niet meer loonend is, al moet erkend dat de goede jaren voorloopig voorbij zijn. In andere districten wordt de kokospalm ook aangetroffen, doch de larve van een Castnia doet daar zooveel 
schade, dat de teelt van het gewas zich daar alleen als een niet belangrijke cultuur heeft kunnen handhaven.

Er zijn nog verschillende andere gewassen te noemen, met de teelt waarvan de kleine landbouwer zich als bijcultuur onledig houdt. Zoo worden overal kleine aanplantingen van mais, pinda, erwten en boonen in verschillende soorten aangetroffen. Maar deze gewassen hebben niet de beteekenis voor den kleinen landbouw van de drie hiervoren besproken producten.

Ook de teelt van vruchten neemt op de meeste perceelen een bescheiden plaats in. Het belang, dat deze teelt in de toekomst voor den kleinen landbouwer kan krijgen wordt over het algemeen niet ingezien of erkend. Er zijn verschillende grondsoorten in Suriname, die goede citrusvruchten en ananassen van uitstekende kwaliteit voortbrengen. Coronie en het Paragebied b.v. leveren ananassen van uitmuntende kwaliteit, terwijl bijna alle niet te zware gronden saprijke, geurige sinaasappelen en behoorlijke grapefruit geven. Maar de cultuur van deze vruchtensoorten kan niet tot ontwikkeling komen, zoolang men daarvoor geen buiten Suriname gelegen afzetgebieden heeft weten te vinden.

Wij hebben in deze korte schets willen weergeven hoe de landbouw zich in de laatste decenniën in Suriname heeft ontwikkeld en hoe de toestand op het oogenblik over het algemeen is. In een volgende bespreking willen wij een poging wagen om aan te geven langs welke lijnen men naar onze meening den grooten zoowel als den kleinen landbouw tot meerdere ontwikkeling kan brengen. 